一総 説 一

家畜の下垂体前葉の形態と機能

見上晋一

岩手大学農学部家畜解剖学教室, 盛岡市 020

\title{
Functional Morphology of the Adenohypophysis of the Domestic Animals
}

\author{
Shinichi MIKamI \\ Department of Veterinary Anatomy, Iwate University \\ Morioka-shi, 020
}

緒

\section{言}

下垂体前菜怯視床下部の支配を受的て生殖腺家含各 種内分泌腺の機能索体液的に調整する中心器官で，特に 性腺, 副腎, 甲状腺などの譏能をはじめ全身の物質代謝

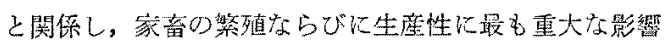
を与えている器官である. 現在，下垂体前蒋为らは卵胞 刺激ホルモン (FSH), 黄体化ホルモン (LH), 催乳ホル モン(プロラクチン, PRL), 甲状腺刺激ホルモン (TSH), 副腎皮質刺激ホルモン (ACTH)，および生長ホルモン (STH) の6 種類の木ルモンが分礼されることが確認さ 九ており，こ和ら壮寸べて生化学的に分離抽出され，乙 の化学的特性p生物学的活性が明らかにさ机ている。 た ACTH などなミ，酸配列が明らかにされて合成品 殿実用化される時代に入っている。しかし下垂体前薬の 構造住複雑で，動物種によってもかなりの相異定示し， その機能の複雑さと相まって, 形態学的にはなお多くの 未解決の問題安残している。下垂㑈についての非態学的 研究法は現在では著しく発展し, 位来汃ら用いら机てき

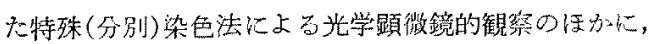
物質や醉栗などを検出する細胞化学的方法, 免没細胞化

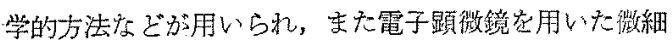
權造の面少らの細胞学, 細胞化学, 免疫細胞化学などの

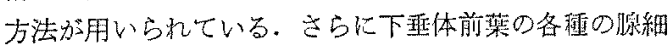
胞の機能空推定方るために，下垂体の栖的器官の摘除，

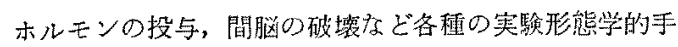
法が取り入れられ，光学㧍よび電子影微鏡による観察に

日畜会報，45,(2)：51-61.

よって，前藻の腺細胞の機能的分類が武子られている。

このように下垂体前耗の研究は最近の4半世紀に医 学, 生物学の分野の花型として登罚し，今やその開花期 にあると言っても過言では流い，現在，下重体前菜の研 究については形態学的研究たけです 1000 編に余る窬文 があり，今回の総説では到底そのすべてを紹介すべくす ないが, 特に組䋘, 発生, 細胞学, 微細構造を含已形熊

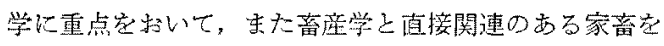

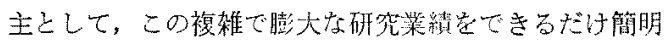
にをるめて紹介したい。

\section{下垂体の構成と発生}

哺孚類では下重体性脳底に突出している小体で，朕庭

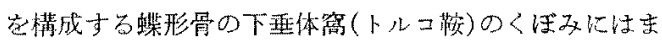

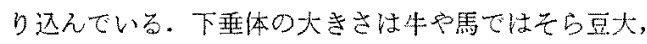

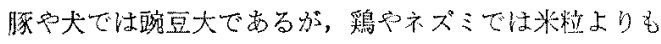
小さい，下垂体は前䒚(遠位部)，中聞部(中間葉)，隆起

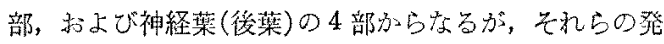
達程度性動物種によってー棈ではない, 同じ哺乳類でも

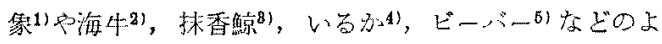

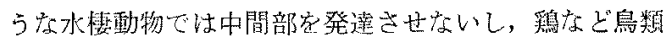
では中間部范众除する $6,7,8$ 。またへビ，魚類，円口類な どけ隆起部至もたない。

発生学的には神経程注神経性の漏斗突起加ら起こる が，他の3部はすがて外胚菜性の口窝の上皮に目来小 る. その発生定見ると犬や猫ては体辰 $6 \mathrm{~mm}$ 程度の胎韭

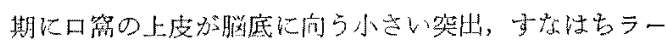




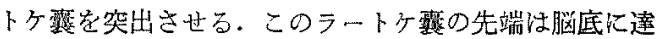
し，その基部はくびれて，やがて口腔との連絡家断っ。

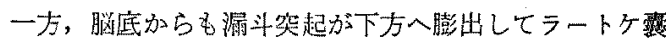
の先端と接着する。漏斗架起はやがて下垂体神経葉倸分 化しまたラートケ露の先端は著しく肥厚して下垂体前 葉となるが，その先端，後方に向って神経葉と接する部

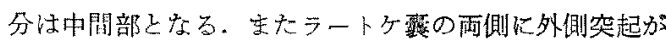
出て，これが漏斗突起の基部に向って伸び部分は隆起 部(これ注脳底の灰白隆起に接するからこの名があるに なる、ラートケ露の内腔注発生の途中で消失することが 古るが，前菜已中間部の閭にはさまって狭い下垂体䐋と して遗残吉ることが多い，特に牛や豚てはこ机方顕著で ある。

下垂体の形態発生については古くは HERRING'，ATWELL ${ }^{10}$, SCHWIND11) らに上。て研究さ机, 最近で注, GlydoN $^{121}$, ConkLin ${ }^{181}$, CAmpbell ${ }^{141}$ らの研究为泫る。 鳥類では RAHN ${ }^{6)}$, PAYNE ${ }^{16)}$ らの研究多あるが, WINGSTRAND ${ }^{81}$ によってその形態発生注完成された钼がある。 現在では電顕定用いた下垂体の細胞発生の研究 ${ }^{10,17,18) か ゙ ~}$ 盛えで，特て光影による観察との比較において，より詳 細な細胞分化の過程と時期定決定しょうとする試み分 多い.

\section{下垂体の区分と構造}

下垂体泣通常つぎのように区分される。

\begin{tabular}{|c|c|}
\hline 神経性下垂体 & 正中隆起 Eminentia mediana \\
\hline Neurohypophysis & $\begin{array}{l}\text { 神経葉 } \\
\text { Pars nervosa (neural lobe) }\end{array}$ \\
\hline $\begin{array}{l}\text { 腺性下琴体 } \\
\text { Adenohypophysis }\end{array}$ & $\begin{array}{l}\text { 隆起部 Pars tuberalis } \\
\text { 中間部 Pars intermedia } \\
\text { 前葉(㬊位部) Pars distalis }\end{array}$ \\
\hline
\end{tabular}

正中隆起と神絰葉はともに漏斗突起加ら起とり連続す るが，両者の違いは血管分布で，閒脈柔に流入する血管 蠸を受けている部分は正中隆起で，一般静脈流入寸る 血管堂受けている部位は神経菻である。

腺性下垂体は隆起部，中間部，前葉(遠位部)の 3 部汃 らなる。隆起部は正中隆起を䍂う腺性正中隆起亡門脈を

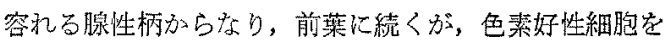
含蚞ない点で前菜とは異なる。

中間部は神経葉に接した腺菜の一部で，組織学的には 一様な塩基好性細胞加らなり，その量は動物種によって 著しく異なる。ある耗の動物(犬，猫)では中閒葉として 発潐し，神経䍅を包むるのるあるが，牛や羊ではこの発 達が恶く，この葉の一部，下垂体腔に面する側的前葉組 織からなる191。このような前葉が分離してできた層をウ ルゼンの円鉭 (cone of WULZEN) と呼忍.
前葉または遠位部怯中閒部范除く腺葉全体点占める。 この葉は数種の色素好性細胞が混在した組織からなる。 中間部を欠く動物（象, 鲸, 鳥類など）では腺葉全体が 前葉細胞に似た各種の色素好性細胞を含みこれんら中 に性中間部細胞に相当する細胞务含まれている可能性が ありまた腺葉は中間葉ホルモン (MSH) を含む。

家畜の下垂体前葉では各型の腺細胞忹すべて均等に分 布している訳ではない。酸好性細胞の多い酸好性細胞層 （周辺部）乙塩基好性細胞の俱勢な塩基好性細胞層があ る.隆起部に接し，それがら前葉の前腹側中央部に伸び 当塩基好性細胞層注 DAWSON と FRIEDGOODD0,211 亿よっ て Zona tuberalis 隆起層と㭔ばれ，その後多くの陠乳頑 ではこれに相当する部位があることが知られている8,221. このような下垂体の層形成は細胞分布の相異のみなら ず，部位による機能的な相異があること定している。

\section{下垂体前葉細胞の分類と名称}

下垂体前葉の細胞型の区分および命名については従来 から多くの試みがなされたが，現在でもな著しく混乱 していると言わさるを得ない，分類法には純粋们形態学 的あるいは染色性による方法，細胞化学的性質以上る方 法，単練にギリシヤ語の交字を用いた命名法などのほか， に，現今では分泌するホルモン名を冠した名称が多く用 いられている.

下垂体前葉細胞は最初に SCHÖNEMANN28) によって，分 泌顆这の染色性によって酸好性細胞, 塩基好性細胞およ び色素㨀狌細胞(主細胞)の3 型に分けられ，さらにとれ らの細胞型はそれぞれ異った分泌機能を有することが明 らかにされだ2). その後, 6 種類の前葉ホルモンの存在 が明らか炕なるにつれて，前䒚ホルモンがそれでれ独立 した細咆型から分泌されると考克るならば，6種類の細 胞型がある心゙きで，末知の細胞型はこの 3 者のいゔれか に会をれるもの之考えねばならず，細胞を 3 型にの父分 類するのでは不都合となった，そこで各ホルモンの分泌 細胞をより合理的に説明するために細胞型をさらに細分 する試みがなされた。すなおち従来は同じ酸好性細胞と されたものでも, 酸性色素への親和性の䔔いたよって, オレンジ好性細胞 (orangeophil), カルミン好性細胞 (carminophil), エリスロシン細胞 (erythrosinophil), 酸フクシン好性細胞 (fuchsinophil) などと細分されるよ らになった。一方, 塩基好性細胞の染め分けは難かて く、フルデハイドフタシン染色 (AF)，フルシアン青染 色 (AB)，アルデハイドチオニン染色 (AT)，PAS 反応 など各種の染色法を発達させたが，最近では PAS 反応 と塩基性色素汇対する 親和性をもとに $\mathrm{AF}$ 十細胞， $\mathrm{AB}$. 
十細胞, PAS 赤細胞, PAS 紫細胞などと呼ぶこともあ る。をた酸性色素之塩基性色革の両者に親和性をむつ細 胞を雨好性細胞 amphophil と呼び，中性色素に染まる ものを中好性細胞 neutrophil と呼ぶことるある。

いずれにしても從来のような色标親和性のみによっ ては6 種類の細胞を命名することは困難であるので， ROMEIS ${ }^{25)}$ はギリシヤ帒の頭文字をとった命名法を提唱 し，酸好性細胞を $\alpha, \varepsilon ， \eta$ 細胞に分け，塩基好性細胞を $\beta$ ，ठ，执よびr細胞に分けた。 RomeIs のタレゾフタシ

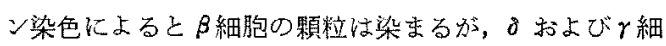
胞の顆数は染李らない.フザン染色では $\beta$ 細胞とる細胞 の顆粒の染め分け汢困難である. その後 GOLDBERG 乙 CHATKOFF ${ }^{26)}$ は MAsson のトリクローム染色によって紫 色に染まるら細胞定追加し，TIXIER-VIDAL27) は鳥類で $k$ 細胞を区別している。しかしこの分類法にも研究者の 間に多くの混乱がある.例えば HALMI ${ }^{38,39,80\rangle} の \beta$ 細胞

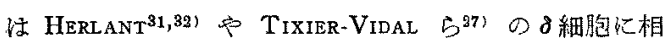

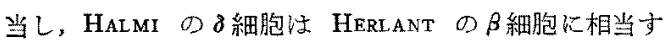
る. 、ずれにしてもこの命名法它用いるためには各整の 染色法によるおのおのの細胞型の染色性についての詳細 な記載が必要でありまた異った染色法を用いた場合に は連続切片法による各細胞型の確実な同定が必要であ る.

最近，电っと多く使用されている命名法は各細胞型

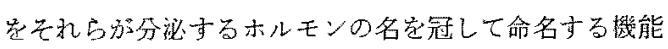
的命名法である。これは最初に PURVES と GRIESBACH ${ }^{33}$, 84,35,36) Kよ二て生殖腺刺激細胞 gonadotrophs, 甲状腺 刺激細胞 thyrotrophs，副腎皮質剌激細胞 adrenocorticotrophsなどと井いられたが、VAN OORDT"37は はこれ 己らに略して, STH 細胞, ACTH 細胞, TSH 細胞, FSH 細胞, LH 細胞, LTH (PRL) 細胞と呼ぶこと定提 晿した。この力法は細胞の機能との関連については将も 明解な命名法でるるが，この命名淕学用いるためには各 細胞型の機能が明解に確認されていることが必要であ り，機能の不明確な細胞には適用できない。しかし摔近 は䖝光抗体法や醉㽝抗体法などの兔疫細胞化学户電子顕 微鏡の利用などによって，各細胞型の機能はしだいに明 確になりつつかるので，この分野ではこの命名法が括も に用いられて和り，今媛使用すべき学名としてむ最も合 理的な⿻コ一考えられる。

\section{前葉細胞の染色性と細胞型}

\section{1. 前葉細胞の染色性}

前葉細胞を染め分けるために戈もに朋いられてきたす 法は HEIDENHEIN のフザン染色 ${ }^{88}$, MALLORY 染色の
Crossmon 変法 ${ }^{89}$, Severinghaus 染色 ${ }^{40)}$, GoldBergChaIKoFF のトリクローム染色 ${ }^{26\}}$, HERLANT のテトラク ローム染色 ${ }^{31)}$, GOMORI のアルデハイドフクシン (AF) 染

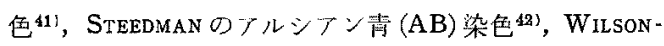
EzRIN のPAS-オレンジ Gーメチル青 (PAS-OG-MB) 染 色 ${ }^{43)}$, PAGET-ECCLESTON ${ }^{44)}$ のフルデハイドチオニンー PASーフォース卜緑(AT-PAS-FG) 染色などである。こ れらの染色法またはその組名せによって，前菜細胞を 6 型に譈別することがでる。これらの特殊染他では絧 胞の生座物口分泌顆粒染め分けているものが多 いしたがって染色法としては細包質の基質をほこえど 染めないて，分泌顆椟のみを強く染好色素名望むし

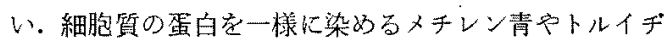
ン青などの算純な塩基性色絜や対称染色として用いられ る酸性色素はこの目的には效果がない，酸性色素で特別

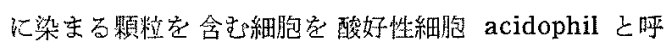

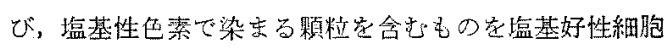
basophil，两者に染まる顆粒走含むもの两好性細胞と 呼ぶ. 酸好性細胞をさらに細分して染め分けるために才 レンジG，酸フタシソ，エリスロシン，フゾカルミンな どの酸性色絜の混合液が用いられる。酸好性顆粒はオレ УシGで橙色に染まるものとフタシンなどで赤他に染ま るものとに区別ができる。これはそれぞれの顆粒圶櫣成

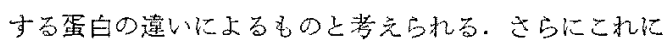
アニリン青やメチール青などの笽基性色素による染色を 重放ると，塩基好性顆精山青，紫，青紫，赤紫などの色 に染的分けることができる。

紬胞型炭区别するためには，才のおのの細胞の色が鮮 やか心区分されて却り，互いの閏に中間的な色調のもの

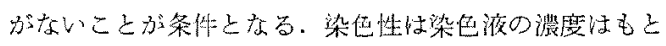
Jり，染色郝間，染色前後口処理(媒染と扞色)，各染色 の・ランスなどで著しく翼なり，1 つ0色素による染色

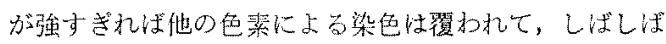
単染色のように見光ここがある。したがって下琟体の

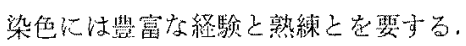

东た特殊染他に上って細胞型を区分するためには，細

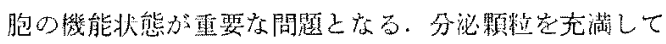

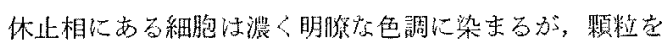
放出している分泌相にある細胞は，貯藏された顆䊓が少 ないために色調は淡く，細胞留の需白や核较の染色にか

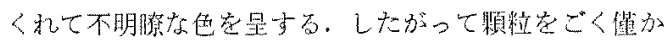
しか含安ない細胞は酸好性細胞か塩基好性細胞かの区別

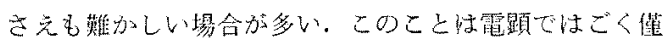

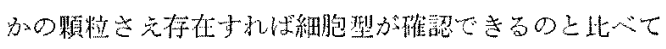

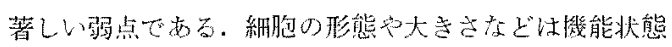


見 上

によって大きく変化するので，正常な埸合は細胞型の区 別にはほとんど役立たない。

ざらに下重体の細胞の染色性は動物種によっても箸し く異なる。元れは動物種によ。て各細胞型の比婆が買な るばかりでなく，染色反㤐の強さや性格が罢なるからで ある。このこと毢物種によるホルモンの特巽性による ものかも知れない，哺乳動物のなかで各細胞型が比較的 染め分け易い動物は，犬，猫，コウモリ，牛，緬羊など で、ネズミやモルモットなごでは酸好性細胞を2型に区 別することが難かしい，特に㗖などの鳥頑で注分別染色 による細胞型の区分はきわめて困難である.

一方, 前菜木儿モンのう古 TSH, FSH, LH 㹥炭水 化物を含糖蛋白性のホルモンで各ること加ら，炭水化 物の細胞化学的梌出法已してMcManus ${ }^{45}$ に上って開発 されたPAS 反応がしばしば細胞型の染め分けに用いら れている。実際に下垂体で程基好性細胞が PAS に反

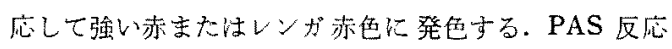
は反応の機構がわかって拉り，従来の経駼的な特殊染色 法と比べると細胞化学的な根䧴がある. PAS 反応と組 み合わせた特殊染色法として WILSON-EZRIN48)による PAS-OG-MB 染色や, PAGET-Eccleston ${ }^{44}$ によるATPAS-FG 染色などが開発され，下垂体の細胞学の研究 に大きな貢献老与えている. 緗胞化学的方法として法こ の他に燐脂質を染好る BAKER ${ }^{46)}$ の酸一マチン法や $\mathrm{SH}$ 基を染るるための BARRNETT-SELIGMAN(4) 法などが用い

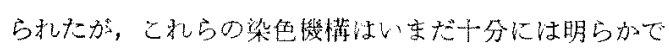
ない.

\section{2. 酸好性細胞}

酸好性細胞に 2 型があることは多くの動物について明 らかにされている。この2 型の酸好性細胞它最初に区分 したのは DAWSON と FRIEDGOOD ${ }^{20,211}$ て，猫上鬼の下垂 体前摹でオレンジ Gで橙色に染まるオレンジ好性細胞 (orangeophil， $\alpha$ 細胞) とアソカルミンで赤色に染まる カルミン好性細胞 (carminophil， $\varepsilon$ 細胞) 区斺した。 その後,これらの2 型の酸妚性細胞性牛 48,49$)$, 緬羊 50,52 ,

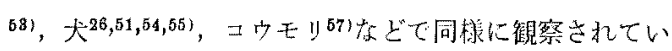

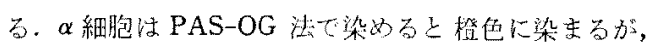

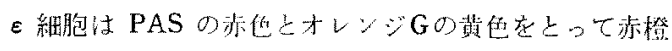

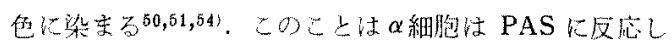

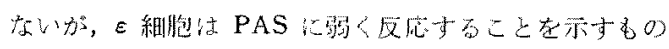

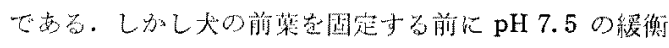

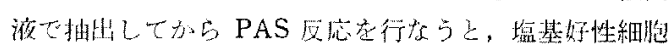
の顆粒は溶出するが，カルミン九性顆精は抽出されない

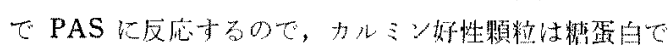
はなくて不溶性の蛋白であららと考兄ら机る ${ }^{54}$ 。また
$2.5 \%$ トリクロール酰酸で抽出してる $\alpha$ 細胞もを細胞も 顆䊀は抽出されない，燐脂質検出するための BAKER の酸へマチン法(6)で法 $\alpha$ 細胞もを細胞もともに顆粒が強 く反応し50,51)，LANDING-HALL のジアゾ青B $B^{58)}$ で酸好

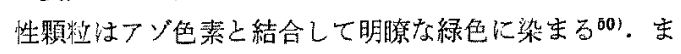
た SH 基 (sulfhydryl および disulfide group) 究め るための BARRNETT-SELIGMAN ${ }^{47)}$ 法では酸好性細胞のみ が染まることが認められたが599，この染色はZZENKER 液 で固定した材料しか反応しないので, 純粋に cystineの 存在に上るとは言い難い601.

酸好性細胞が生長ホルモン分泌細胞でることは 1927 年に CusHING と DAvidofF ${ }^{611}$ が人の末端肥大症 acromegaly が酸好性細胞腫によることを発見して以来, 多 くの観察によって確かめられている。例光就小マウス や小びとでは酸好性緇胞が欠除していることが知られて

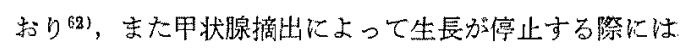
酸好性細胞が消失することが多くの研究者によって報告 されている(8,54). 甲状腺摘出によって消失する酸好性細 胞はオレンジ好性細胞 ( $\alpha$ 細胞)であってカルミン好性 細胞 $(\varepsilon$ 細胞) には变化がないので65， $\alpha$ 細胞が生長木ル モン分泌細胞であることが明らかである。その後，多く の免疫細胞化学的研究はこの結諭を追証している.

酸好性細胞の他の一型, カルミン好性細胞 ( $\varepsilon$ 勫胞) は 動物の妊娠期や泌乳期汇活動的になることからプロラク チン (PRL) 産生細胞と考无られる，このことは猫 ${ }^{20,21,}$

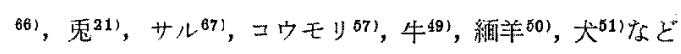

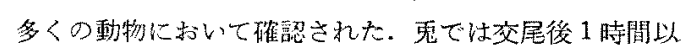
内比排莸起こすためのLH の分泌が起こるが，この時 期には LH 分议細胞と思わ的名塩基好性細胞の顆粒が放 出される。交尾後 3-4 時間でカルミン好性の顆粒が蓄䅡 さ机，続く 10 時間の間にこの顆粒は濑次放出される ${ }^{68)}$. このことからを細胞は LTH (PRL) 分泌細胞であると 考えられ，猫でも同㥞の観察が行なわ扎ている ${ }^{661}$ 。また コウモリでは繁殖期に $\varepsilon$ 細胞は 2 相の分泌活動它するこ

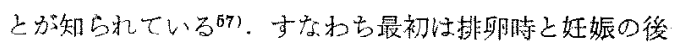
半期で，つぎは分婏の直前之流乳期に分䎵活動方盛んに

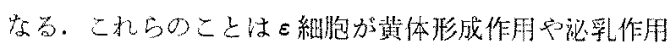
をもつプロラタチンを分泌することを示すものである。

\section{3. 塩基好性細胞}

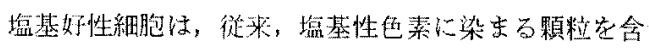
さ細胞を意味していたが, 最近ていこれらの颗糊はPAS 反応に陽性の糖蛋白它念しとが明らかとなったので， 粘液細胞 mucoid cell と呼ばれることもある. 程基好

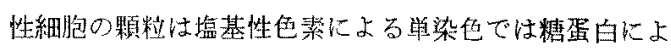
る赤紫色の異調染色 metachromasia を示寸。前葉小儿 
モン゙の糖蛋白に着目して下垂体前菜にPAS反応を行い， 実験的变化と対照して TSH 細胞, FSH 細胞, LH 細 胞を最初に区别したのは PuRves とGRIESBACH ${ }^{93-36)} て ゙$ ある。しかし，分”别染伊でこ机らの3 型在区別すること

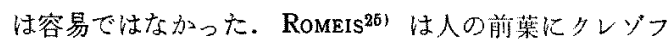
クシン染色を朋いて，これに好染する $\beta$ 細胞と染まらな いる細胞および $r$ 細胞の3型の塩基好性細胞を区斺し た. フザン染色では $\beta$ 細胞と $d$ 細胞の分別は图難である が， $\gamma$ 細胞は容易に識別できる。の後，弾性線維の染 色法として知られる GOMORI $\sigma$ AF 染色 ${ }^{41}$ が $\beta$ 細胞を 撰択的に染めることが発見されてた ${ }^{29,84,35)}$ ，乙かしこの染 色曲固定法や之の後の処理，あるい注染色液の熟成度な どによって一定ではなく，場合によっては他の篮基好性 細胞客染める尔点がある。また STEEDMAN ${ }^{42}$ にるるAB 染色が $\beta$ 細胞を揩択的に染色することが報告されてい 万56).さらにPAGET と ECCLESTON はAT 染色を開発 したが，この染色性は AF 染色とはかなり買なり，る細

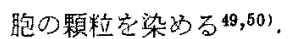

多くの動物において 3 型の塩基好性細胞があることが 知られている ${ }^{84,35,86,43,44,52,58,67,69,70,71,78)}$. こ秃らの3型 注 WILSON 2 EzRIN 0 PAS-OG-MB 染色(3) HERLANT $5^{31}$ の AB-PAS-OG 染色, PAGET-ECCleston $の$ ATPAS-FG 染色44索どで染め分けることができる．3型 の塩基好性細胞上注 ROMEIS ${ }^{251}$ ○ HERLANT ${ }^{81,821}$ の $\beta$ 細 胞， $\delta$ 細胞， $\gamma$ 細胞であり，機能的には TSH 細胞， FSH 細胞， LH 細胞である。一般にTSH 細胞 ( $\beta$ 細胞, HERLANT の $\delta$ 細胞) は AF る. $\gamma$ 細胞 ( LH 細胞) は PAS に弱く区応立るが，AF や AB には pH 3 で酸化しても染まらないので，古る 種の動物では酸好性細胞をたは闻好性細胞に含まれるこ と㫐るる $31,32,49,50$.

WILSON દEZRIN ${ }^{43)}$ は PAS-OG-MB 染色で 下垂体の塭基好性細胞と PAS 紋胞と PAS 紫細胞の

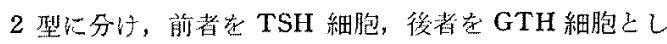
た。過ホルミック酸で酸化した後, AB-PAS-OG 染色 を行なうと塩基好性顆粒は $\mathrm{S}$ 型と $\mathrm{R}$ 型の 2 型化分けら $れ^{60)} ， \mathrm{~S}$ 型顆䊉注比較的高灌度に cystine GTH 細胞に含まれるる゙，R 型顆粒はTSH 細胞に含ま れると言われる。. MIKAMI $5^{501}$ 怯 AT-PAS-FG 染色に

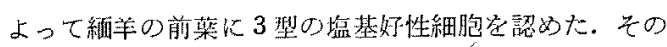
1 型はAT 強く染まり青黑也て，2型は AT に弱く

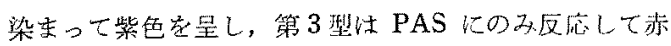
色を呈した。速続切片の比較によって1型は $\partial_{1}$ 細胞 ( $\mathrm{LH}$ 細胞)， 2 型は $\partial_{2}$ 細胞 ( $\mathrm{FSH}$ 細胞)， 3 型は $\beta$ ( TSH 細胞)肪よびら細胞（ACTH 細胞）であること学明らか
KLた.

ラットにおいて FSH 細胞と LH 細胞の染め分け涪 はまだ倠立されていない。これらは同一細胞であること も考えられらし，失異った細胞型であっても染色性が 似ていて娍别が不可能な場合もある。このような場合，

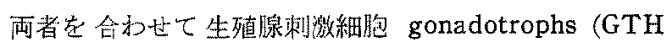

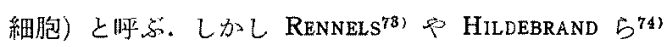
は PAS-OG-MB 法を用いて，粗大な紫色の䏝精を含む

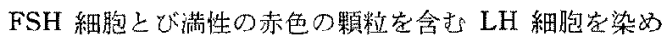

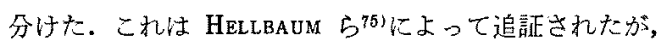
他の班究者江成功しなかった. FSH 顆粒と LH 顆粒定 見分けるために PURVES ら ${ }^{58,541}$ は緩衡液による抽出武験

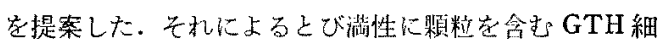
胞は顆精が溶出し難く，生た LH 活性のみが残ったの でこれらを LH 細胞とした，BERRNeTT $5^{76}$ 社 $2.5 \%$ トリタロール酷酸による抽出妃よって同様の結果を得て いる。

\section{4. 両好性細胞}

GOLDBERG 乙 C HAIKOFF ${ }^{26)}$ は大で第 6 の細胞型として

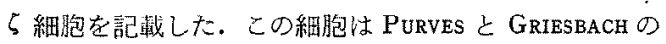
pale 細胞 ${ }^{52}$ やら 細胞 ${ }^{53}$ に相当し, 明膫な染色珄を示す 顆稙を含まない点て RomeIs $\sigma \gamma$ 細胞に相当する、アザ ン染色では淡い細胞質中に不規則に分散した淡紫色の顆 粒が認められる. MIKAMI ら年,50,511はトリクロ一ム染色 でこの細胞を両好性細胞とした，顆粒はPAS に弱く反 店するが，AFやAT, AB に染まらず, PAS-OG-MB 染他や AB-PAS-OG 染色で赤色老呈するのて, 人 ${ }^{681}$,

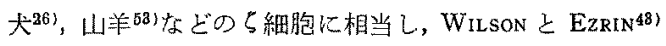
の PAS 赤細胞, EZRIN と MURRAY ${ }^{781}$ ○ $\beta_{1}$ 細胞, PEARSE ŁVAN NOORDON ${ }^{73)} の \mathbf{R}$ 帮細胞に相当する。副 腎孛摘出した犬や羊ではら細胞は著明に肥大して副堅摘

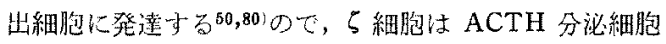

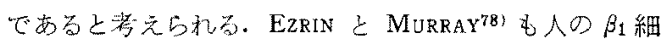

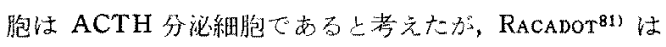

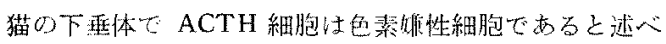
ている.

\section{前葉の免疫細胞化学}

\section{1. 蛍光抗体法}

䖝光抗体法は 1951 年に ConN ${ }^{83)}$ よって閉発され，そ

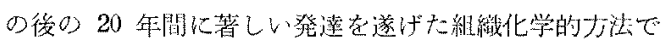

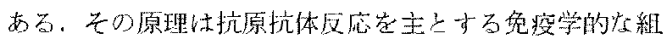

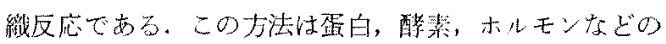

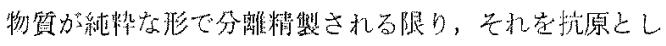

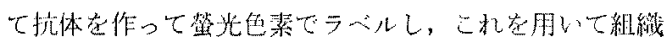


見上

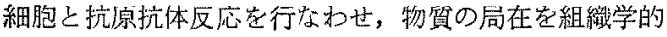
に検出する方法である。したがって細胞内における特定 の物質やホルモンなどは免疫学的に直接組織上に証明で きるわけで，下垂体では各ホルモンの分祊細胞を同定す るためには最杂俊れた方法の1つと言光よう。

下垂体では生長木ルモン分䎵細胞の同定が最初に行な われ，酸好性細胞 ( $\alpha$ 細胞) が生長ホルモン分泌細胞で あることが明らかになった モン $(\mathrm{STH}, \mathrm{GH})$ 它分䎵する酸好性細胞とプロラクチン (PRL) を分䎵する酸好性細胞は别種の細胞型であるこ とが明らがされた年,87,881. EMMART ら ${ }^{87,88)}$ は羊の PRL を抗原として抗血清を作り，抗PRL ク゚ロブリンを 䖝光色素でラベルして，猫87 とラット881の下垂体を染 め, 酸好性細胞に PRL を検出した. 椎野ら ${ }^{89}$ ) と鬼の下垂体の凍結乾燥切片に羊の GH と PRL を抗原 とした䖝光抗体法を用い，GH と PRL はそれでれ買っ た2型の酸好性細胞に存在すること崖明らかにした。

NAYAK ら ${ }^{90}$ は牛の下垂体で注羊のPRL に対方螢光 抗体性 AT-PAS-OG 法で PAS に弱〉染まる酸好性細 胞上反応するが，GH は OG のみ汇染まる酸好性細胞 に存在するととを認的， $\alpha$ 細胞が STH 細胞でありを細 胞が PRL 細胞であると言う従来の細胞学的研究の結果 を裹付けた。 また STOKES と $\mathrm{BODA}^{811}$ は羊の $\mathrm{GH}$ と PRL に対寸る螢光抗体を用いて，羊の胎児の下垂体の GH 抢よび PRL の分布とその初期発生について検討し, 抗 $\mathrm{GH}$ に上る䍃光新生児户成熟羊では aurantiphil （ $\alpha$ 細胞）の多に検出され，胎児では胎生 43-53 日に始 めて出現したが，抗 PRL 䖝光は erythrophil（ 細胞） に諗められ，胎生 80-88 日で懒出されたと述へ，この時 期は染绝に上って $\alpha$ 細胞 (胎生 73-95日) 飞 $\varepsilon$ 細胞 (胎生 105-125 日）が梌出される封期上りも著しく早いことを 明らかにした。

ACTH 細胞については多くの研究分新り，PAS に弱 く反応士るR型細胞であるとする意見が強いが，BREUS・ TEDT ${ }^{911}$ は合成 $\beta^{1-2}$ corticotrophin 拈よび抽出豚 ACTH に対寸总鬼抗血清の䖝光抗体によってラットの ACTH 細胞定换出し，PF-AB PAS OG 染危による R 型およ びS 型粘液細胞は陰性で，色素婄性細胞または多角細 胞多今 ACTH 細胞であると述べている。最近 DuBors92) は签光抗体法によって牛，暃，豚の中間部の細胞は $\alpha$ 和よび $\beta$-MSH分竧するが，前䒚では ACTH 細狍は ACTH と $\beta$-MSH 分分泌すると述べている.

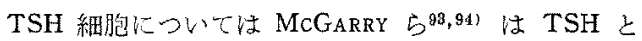
ACTH は同一のR 型細胞から分泌されると述心゙，BrozMAN $^{95)}$ はTSH 細胞法 AB 陽性のS 型緗胞で西り,
ACTH 細胞とは区別されると述べて一致しないが，こ 机怢溃光抗体法の場合, 对照染色が難かしいことに原因 するものと考えられる.

FSH 細胞と LH 細胞化ついては MIDGLEY ${ }^{88)}$ は LH 細胞は AF おょび PAS 陽性の $\mathrm{S}^{\prime}$ 細胞であると述べ, $\mathrm{K}_{\mathrm{RACHT}}$ ら $^{97,981}$ は LH は $\mathrm{S}_{1}$ 型細胞, FSH は $\mathrm{S}_{2}$ 型細 胞㑧存在すとし，DUBors ${ }^{991}$ は抗 HCG 抗体と交刃反 応老する牛の $\mathrm{LH}$ 細胞は小型の PAS+, $\mathrm{AB}+$ 細胞で, 前葉のほか隆起部，中間部にも分布し， $\mathrm{PAS}+, \mathrm{AB}-$ の FSH 細胞や， PAS-， AB+の TSH 細胞加ら区別て きると述べている。

\section{2. 酵素抗体法}

NAKANE $5^{1001}$ によって開発された免疫組織化学的方 法で，气の原理洼管光抗体法における管光色素の代りに 醅素を用いる。この䤃素はなるべく動物組織に存在しな い純料なもので，反応様式もわ孙ており，反応最䅂産 物が光顕をたは䇴顥下で可視であるととが必要である。

一般に酵素としては horseradish peroxidase が用いら れ，反応の発色には 3-3'-diaminobenzidine (DAB) が 用いられる。この方法注䖝光抗体法と異なり，反分産物 は永久標本にできるほか，光顕上電顕の両方で観察でき ることである。したがって特殊染色との併用による細胞 の同定や電影任よる微細構造との比較が容易で，きわめ て買れ犬方法で亦り，この方法は今後最を多く用いられ るもの之考充られる。

この方法を下垂体前葉ホルモン分泌細胞の同定に最初

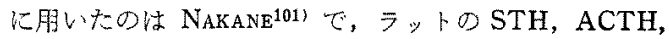
PRL，TSH はそれでれ簧った細胞に分有寸るが，FSH とLHはしばしば同一細胞内に認められることがあるる 述べている.BAKER ら ${ }^{1003}$ 注䤃素抗体法をラットの下垂 体汇応用して GH と PRL を検出し， MASSONのトリク ローム法による対照染色によって，それらが 2 型の酸好 性細胞に別々に存在すること明らかてした。また豚の ACTH に対与る peroxidase でラぶルした抗体を用 い108)，ラットのACTH 細胞は多角形で突起家むった星 状緗胞であり，AFやPAS 海弱染まると述べた。彼 らによると ACTH 細胞は比率は少ないが，中間部に接 する部位や後部定除いて前葉全体に分有し，その大きさ は ACTH の含量の生理的变化化伴って增滅し, 副腎摘 出によって增大するが， cortisol 投与炕よって隇少する という.さらに BAKER ら ${ }^{104}$ 性人の抗 TSH 抗体を用い てラットの TSH 細胞を検討し, TSH 細胞は多角形で AF および PAS 隄性の細胞で細胞索の中央部に位置し， 側菜の正中部之中間部の直下に多く分布するが，背頭側 部には稀であると述べ，また105) TSH 細胞は他の研究 
者によって形態学的にあるいは染色性や分布によって TSH 細胞と言われてきたものによく一致したと述べて

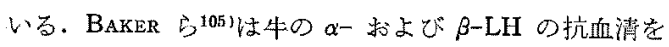
用いてラットの LH 紐胞定検討し， ラットで注 $\beta-\mathrm{LH}$ は LH 細胞を撰択的に染めたが， $\alpha-\mathrm{LH}$ の抗血清は $\mathrm{LH}$ 細胞とTSH 細胞の両者に反応したと述べた。最近， TouGARD ら ${ }^{100}$ l と LH $\beta$ に対するモルモットの抗血清定用いてラットの 下垂体の LH 細胞を光䫓と電影で検討した。そ心絬喿, LH は AB-PAS 染色で紫色に染まる細胞に悲めら水た

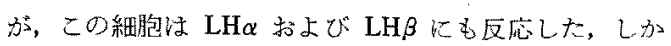
し AB-PAS で青色の細胞は LH $\alpha$ のみに反応したと述 ベている.これを電顕で観察すると2 型の塩基好性細胞

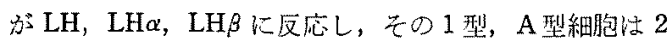
型の球形の分泌顆粒（径 $200 \mathrm{~m} \mu$ と $300-700 \mathrm{~m} \mu$ ) を含 み, 去勢によって肥大して空胞化したが, 他の1型, B

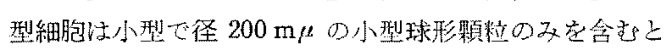

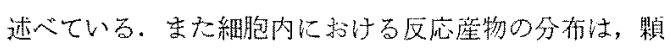
粒に最も強く出現するが，去勢によって肥大した細胞で は緗胞質の一部にも出現し，また粗面小胞体の内腔にも 出現することがあると述心゙ている。

\section{下垂体前葉の微細構造}

近年電子顕微鏡の開発と技術の改良に上って形態学特

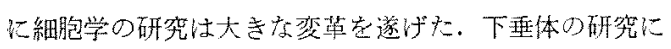
おいても電顕恬今や最る有力なとして尔くことのてきな いものとなった。それは主として電影の高い分解能によ る.下莗体について電顕在最初に用いたのは FERNÁNDEZ-

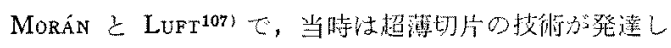
なかったので細胞のスメアーやレプリカについ隹察 し，酸好性顆稙之塭基好性顆粒の大きさが著しく異なる

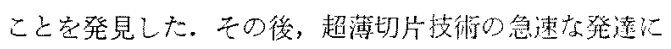
伴って多くの研究が行われた. RINEHART $上 F_{A R Q U H A R}$

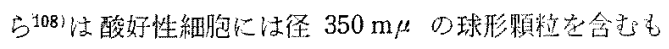
のと, 径 400-700 $\mathrm{m} \mu$ の甽丹形顆粒を合むものとの 2 型

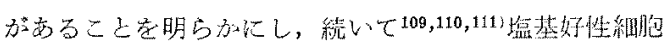
にも2型が西り，その1 型注 TSH 細包て径 $140 \mathrm{~m} \mu$ の 顆稙去含むが，他の1 型は GTH 緗胞で佳 $200 \mathrm{~m} \mu$ の 顆粒を台むこと定明らか儿した。電影による下垂体の研 究はその後 BARNeS ${ }^{112,113)}$, KuRosumi ${ }^{1143}$, HERLANT ${ }^{115}$, 116)らによって発展され，現今では下垂体の砢究者の大 半は電頙を用いていると言える。さらに䉓顕による緗包

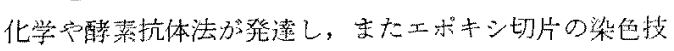

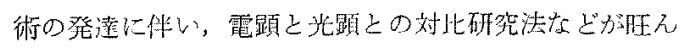
に用いられている49.

\section{1. 細胞の微細構造とホルモン産生機序}

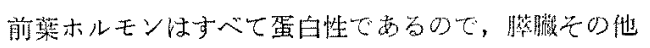

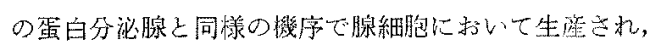

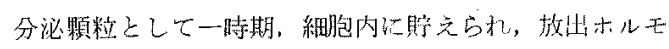
ンの作用汇よって血流中に放出される。したがって前蔡 の腺細胞はよく発達した粗面小胞体やGoLGI 酱置起は じめ，自由リボゾームやミトコンドリア，ラインゾーム などを含を、前葉ホルモンは粗面小胞体に付着するリボ

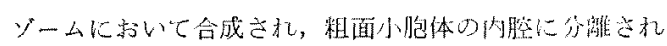
る.この蛋白は GoLGI 装置に通ばれ，ここて滥縮され

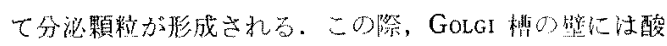
性フォスフォターゼやチアミンビロフォスフォターゼな

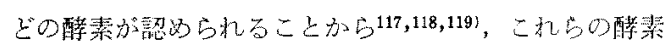

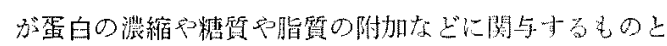

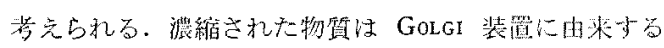

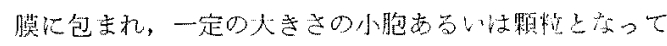

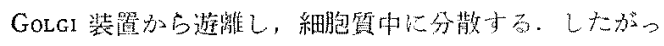
て GOLGI 装置の附近には種々の成熟段階の顆粘が認的 られる. 分泌顆粒の大きさは産生されるホルモンの種類 に上って医潞一定しているので，これが細胞型の区分に 役立つ. 細胞整面仗移動した分泌顆粒洼視㡷下部加らの 放出ホルモン (RH) の刺湤によって細胞膜を通漫して細 胞外(血管周辺腔) 一放出される。放出機序法注じ的顆粒

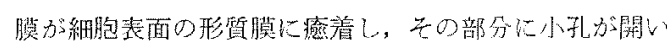

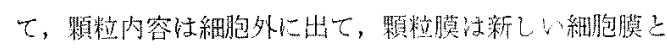
して残る。この形式它關口分泌 emiocytosis と呼儿で

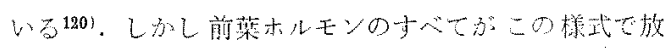

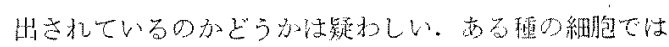

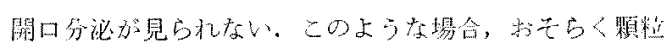

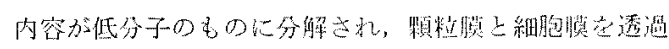

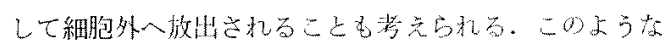

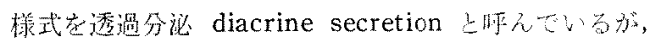
形態学的に寒正することが踓玑しい。

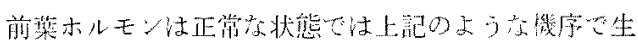
産され，放出さ机ると考无ら机るが，古る緗包の機能が

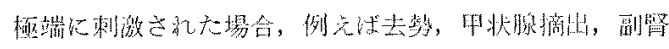

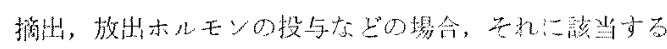

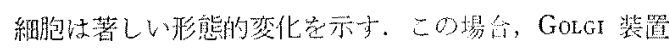
が著しく肥大して細狍質中に分散するとるもに，絴胞倎

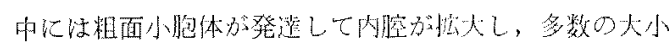
の液胞となって細胞質全体に分散吗方。二扎恬粗面小胞

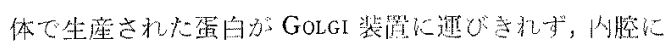

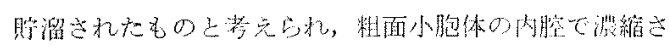

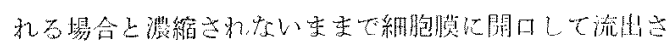

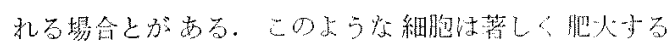


が，分论顆䊓はきわめで稀である。このような細胞の起 源追究することによって，それが分泌するホルモンと の関係を明らか炕することができる。

\section{2. 前葉の各細胞型の特徵と微細構造}

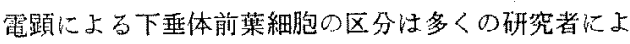
って各暞の動物について行われている 多くは前菜細胞を分泌するホルモンの種類仙合すせて 6 型ないし7型に区分し，本いモン名冠して命名してい る。

\section{1) 生長木几モン分泌細胞 (STH 細胞)}

酸好性細胞の1 檑, オレンジ好性細胞 ( $\alpha$ 細胞) に相 当し，最も高率比出現す吕細胞型である。大きさは中等 度, 円形，卵円形または多角形である。細抱質中に約 $350 \mathrm{~m} \mu$ の電子密な球形の顆粒を含み，粗面小胞体之 GOLGI 装置の発達がよい。しばしば開曰分泌像が認めら れる。特に視怵下部の抽出物や $\mathrm{GH}-\mathrm{RH}$ を投与すると

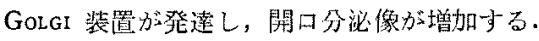

2) プロラロチン分泌細胞 (PRL 細胞, LTH 細胞)

酸好性細胞の他の 1 種，フゾカルミン，エリスロシ ジ, 酸フタシンなどに好染する細胞 ( 細胞)で, 最む 大型で電子密な不規則な形の顆粒を含むことが特徵であ る.顆粒注円形, 卵円形, コンマ型などを呈し、その大 きさは長径 $600 \sim 900 \mathrm{~m} \mu$ におよぶ177,121,128!。 また粗面 小胞体艻著しくょく発達し, 細胞の一端で平行な層板状

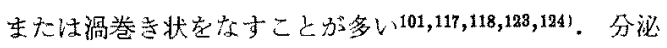
顆粒は坬では交尾後增加し，ラットては泌乳期やエスト 口ヂエン処理によって增加する. HYMer と MCSHAN ${ }^{125)}$ はラットで遠心分画によってこの顆粒苍集め，これが PRL 作用があることを明らかにした。

3) 副掔皮質制激ホルモン分䎵細胞 (ACTH 細胞)

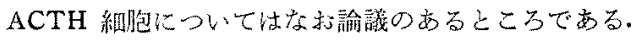

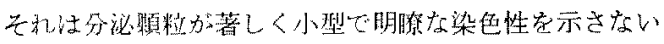
ことから光雅による絬果との比較が容易でないことによ る. しかし同一細胞を光影と電㩆で比較すると, ACTH

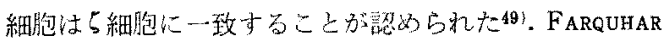
123) 户 KAGAYAMA ${ }^{1271}$ はラットでは顆粒をもたない小胞 細佨がACTH 細胞である名と述べたが，KURosum1114,138，

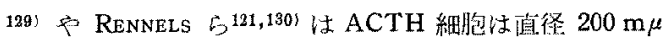

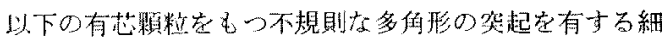
胞であると述べている. ACTH 細胞の分泌顆粒は著し

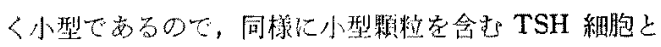

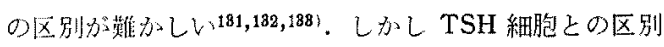
は䅡粒内容が顆粒膜との間に明るい架腙定もつことによ って見分けら机る。しがこの空腺は才スミウム酸固定 では明胉であるが，ダルタールアルデハィド国定で性認
められないことから，固定中に顆粒の一部が溶出するの ではないかとも言和れる180,181)。副瞥摘出によっててれ らの細胞は堌数，肥大して分䎵顆稙を失った副腎摘出細 胞汇発達する。

4)甲状腺刺激ホルモン分泌細胞 (TSH 細胞) 塩基好性細胞の一種, $\beta$ 細胞で， AF や $\mathrm{AL}$ k陽性， PAS-OG-MB 法で PAS 赤に染をる小型多角形の細胞 である. 直径 $100 \sim 180 \mathrm{~m} \mu$ の電子密な小型球形顆粒を 有し，この顆粒は細胞の表面に沿って配列する傾向があ る、しかしこの顆粒の大きさについては異論の苏るとこ るで，動物種によってを異なり，最小 $100 \mathrm{~m} \mu^{186)}$ 加ら $250 \sim 400 \mathrm{~m} \mu^{401}$ までの巾がある. 甲状腺を摘出したり， 放射性ヨウ素を投与する之 TSH 細胞注極度に肥大して 甲状腺摘出緗胞になる。この細胞は GoLGI 装置が著し く肥大し,また粗面小胞体の内腔が拡大してコロイド状 物質を入れた大小梯々の液胞が細胞質全体に出現する。 この液胞は核や GOLGI 装置の周辺部では小型であるが， 細胞の周辺部では大型でまたしばし代内腔に球形また は不定形の暗調物質を容れる。分泌顆粒はほと九ど消失 する.したがっててれらの細胞は著しく分泌機能が高ま り，も早 GoLGI 装置の双に执いて 顆粒を浱縮するゆと りがなく，直接粗面小胞体内で分泌物が形成されている ものと考充られる。しかし，甲状腺摘出細胞の起源につ いては異論もあり, halo 細胞, LTH 細胞, LH 細胞ま たはSTH 細胞から起ると言ら説もある186,187,188).

5) 生殖腺刺激ホルモン分泌細胞 (GTH 細胞)

前築の 2 種の生殖腺刺溦ホルモン (FSH と LH) が同

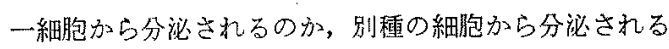
が長い間椧議されたが，まだ完全に解決されたとは言 えない. FARQUHAR と RINEHART ${ }^{1091}$ は去勢ラットに和い て2 型の GTH 細胞を最初に記傤し, FSH 細胞恃搪張 した内腔をるつ粗面小胞体之均等江分布した分䎵颗粒を もつが，LH 細胞は暗調な分泌顆粒の間に floculent な 明るい部分定もつと述べたが，正常な FSH 細胞や LH 細胞については記載していない. BARNEs ${ }^{112,113)}$ はマウ スて FSH 絓胞を区別し，KURosumi と OorA ${ }^{1391}$ はラッ トでBARNESの絬果と同様の 2 型の GTH 細胞を区分し ている. BARNES ${ }^{113)}$ によるとマウスの FSH 細胞は大形 円形をたは卵円形の絸胞で，径 $150 \sim 200 \mathrm{~m} \mu$ の比較的

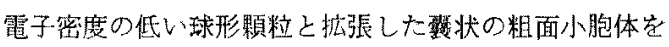
含むが，LH 細胞は小形卵円形または多角形の細胞で， 径 $100 \sim 200 \mathrm{~m} \mu$ のきわめて電子密な球形顆粒を含さ。 GIROD と DUBOIS ${ }^{140)}$ は八ムスターでFSH 細胞恃大きさ の不定な（径 100 180 $\mathrm{m} \mu$ ) 暗調顆精と明るい粗面小胞

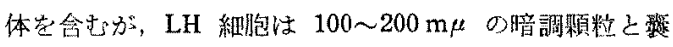


状の粗面小胞体を合をと述べている。しかし現在，分榄 顆粒の電子密度や大きさのみで FSH 細胞と LH 細胞岩 区分すること饬実ではないとする意見も多い(141,142)。

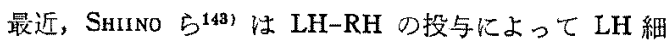
胞から分泌顆粒が放出される像它見ており，MIKAMI 49 も牛で同一細胞の光影と電顕の比校によって, 明らかに 染色性や微細構造の異なる 2 型の GTH 細胞が存在する ことを認めているので，それらの2 型について記藏して おく.

a) FSH 細胞 塭基好性細胞の一種， $\boldsymbol{\delta}_{2}$ 細胞で， AT, MB, PAS に陽性, AF, AB に隍性の顆粒を含も 大型不定形の細胞で，細胞質中には直径 $220 \sim 300 \mathrm{~m} \mu$ の顆精定含む。粗面小胞体江中等度に拡張し，分泌顆粒 の間に分散している。 GOLGI 装犆は発達して輪状をな し，細胞のほ医中心に位置する。去勢すると分䎵顆粒任 減少し, 粗面小胞体の内腔は藷しく㹡張し, 時に注 signet ring 状を呈する.

b) LH 細胞 PAS 陽性の粸粒の含吉塩基好性細胞 の一種, る1 細胞であるが, 分泌顆粒は酸つクシンとフ

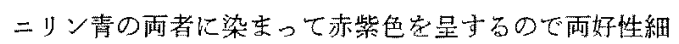
胞とも言える。細胞注中等大，円形または円形に近い多 角形で，細胞質中には径 250 300 $\mathrm{m} \mu$ のきわめて䉓子 密な球形顆稙を充渵している。去茄によって細胞は肥大 し，細胞質がしばしば針金細工㧼茥する。

最近 20 年間に乱りる下垂体前菜的ついての研究の進 展は著しく, 各種の新しい技術の発湑乙ともに, 多数の 重要な知見が得られた。この総説ではそのすバて它紹介 することはできなかったが，特に重要乙思われる知見や 今後の研究の力向亦晙すると考无られる研究について は群しく述心た。この総詵が下瑟体心研究者にとって多

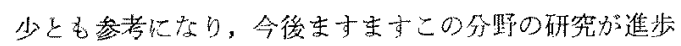
発展すること老望んで止まない次第である。

\section{文献}

1) Wislock I, G. B., Anat Rec 74: 321-328. 1939.

2) Oldham, F.K., D. P. McGleery, and E.M. K. GeILing, Anat Rec 71: 27-32. 1938.

3) Wislock!, G. B., and E.M. K. Geiling, Anat Rec 66: 17-41. 1936.

4) Wislockı, G. B., Arch Surg 18: 1403-1412. 1929.

5) Kelsey, F. O., L. Sorenson, A. A. Hagen, and H. J. Clausen, Proc Soc exp Biol 95: 703704. 1957.

6) RaHn, H., J Morphol 64: 483-517. 1939.

7) RaHn, H., and B. T. PAINTER, Anat Rec 79:
297-312. 1941.

8) Wingstrand, K. K., The structure and development of the avian pituitary. Gleerup, Lund. 1951.

9) Herring, P.T., Quart J exp Physiol 6: 73108. 1913.

10) Atwell, W. J., Amer J Anat 24: 271-337. 1918.

11) Schwind, J.L., Amer J Anat 41: 295-319. 1928.

12) Glydon, R. St. J., J Anat (Lond) 91: 237244. 1957.

13) Conklin, J. L., Anat $\operatorname{Rec}$ 160: 79-92. 1968.

14) Campbell, H. J., J Arat (Lond) 100: 381-387. 1966.

15) Payne, F., A nat Rec 96: 77-91. 1946.

16) Dakoku, S., M. Kinutani, and Y.G. WataNABE, Neuroendocrinol 11: 284-305. 1973.

17) Fink, G., and G.C. SмIтн, Z Zellforsch 119 : 208-226. 1971.

18) Mikami, S., T. HashiKawa, and D. S. Farner, Z Zellforsch 138: 299-314. 1973.

19) Wulzen, R., Anat Rec 8: 403-415. 1914.

20) Dawson, A.B., and H. B. Friedgood, Anat Rec Suppl 1, 70: 129. 1937.

21) Dawson, A.B., and H. B. Friedgood, Stain Technol 13: 17-21. 1938.

22) Hanström, B., Arkiv för Zool 4: 187-294. 1952.

23) Schönemann, A., Arch path Anat 129: 310336. 1892.

24) Smith, P.E., and I.P. Smith, Anat Rec, Suppl 25: 150-151. 1923.

25) Romeis, B., Handbuch der mikroskopischen Anatomie des Menschen, 6-3. 1940.

26) Goldegrg, R. C., and I. L. Chaikoff, Anat Rec 112: 265-274, 1952.

27) Tixier-Vidal, A., Arch Anat micr Morphol Exp 54: 719-780. 1965.

28) Halmi, N.S., Endocrinol 47: 289-299. 1950.

29) Halmi, N.S., Stain Technol 27: 61-64. 1951.

30) Halmi, N.S., Endocrinol 50: 140-142. 1952.

31) Herlant, M., Bull Micr Appl 10:37-44. 1960.

32) Herlant, M., Biol Med, Paris 51: 205-222. 1962.

33) Purves, H. D., and W. E. Griesbach, Endocrinol 49: 244-264. 1951a.

34) Purves, H. D., and W. E. Griesbach, Endocrinol 49: 427-428. 1951b.

35) Purves, H. D., and W. E. Griesbach, Endocrinol 49: 652-662. 1951c.

36) Purves, H. D., and W. E. GriesbaCH, Endocrinol 55: 785-793. 1954.

37) van Oordt, P.G.W. J., Cytologie de l'Adenohypophyse, Ed C. N. R.S. Paris 1963.

38) Lille, R. D., Histopathologic technic and 
practical histochemistry 545 McGraw-Hil B.C. 1965.

39) Crossmon, G. C. Anat Rec 69: 33-38. 1937.

40) Severinghaus, A. E., Anat $\operatorname{Rec} 57$ : 149-175. 1933.

41) Gomori, G., Amer J clin Path 20: 665-666. 1950.

42) Steedman, H. F., Quart J Micr Sci 91: 477479. 1950.

43) Wilson, W. D., and C. Ezrin, Amer J Path 30: 891-899. 1954.

44) Paget, G. E., and E. Eccleston, Stain Technol 35: 119-122. 1960.

45) McManus, J. F. A., Nature, Lond. 158: 202. 1946.

46) BaKer, J. R., Quart J Micr Sci 87: 441-471. 1946.

47) Barrnett, R. J., and A. M. Seligman, J Nat Cancer Inst 54: 769-803. 1954.

48) Gilmore, L. O., W.E. Peterson, and A.T. Rasmussen, Minn Agr Exp Stat Tech Bull 145. 1941.

49) Мiкамi, S., Z Zelforsch 105: 457-482. 1970.

50) Mikami, S., and T. Daimon, Arch histol jap 29: 427-445. 1968.

51) Mikami, S., and K. Ono, J Fac Agr Iwate Univ 2: 440-448. 1956.

52) Purves, H. D., Sex and internal secretion, 3ed Edn. pp. 161-239. ed W.C. Young, Willium \& Wilkins, Baltimore. 1961.

53) Purves, H.D., The pituitary gland, Vol. 1 pp. 147-232. Ed G. W. Harris, and B.T. Donovan, Butterworths, Lond. 1966.

54) Purves, H. D., and W. E. Grieseach, J Endo. crinol 14: 361-370. 1957.

55) Hartmann, J. F., W. R. Fain, and J. M. Wolfe, Anat Rec 95: 11-27. 1946.

56) Herlant, M., and S. Racadot, Arch Biol 58: 217-248. 1957.

57) Herlant, M., Arch Biol 67: 89-180. 1956.

58) LaNding, B. H., and H. E. HaLL, Stain Technol 31: 193-196. 1956.

59) Ladman, A. J., and R. J. Barrnett, Endocrinol 54: 355-360. 1954.

60) Adams, C. M. M., and K.V. SWettenham, J path Bact 75: 95-103. 1958.

61) Cushing, H., and L.M. Davidoff, Rocheffeller Inst Med Res Monogr 22: 1-131. 1927.

62) Hewre, T.F., J Endocrinol 3: 397-400. 1943.

63) Geschwind, I.I., and C.H. LI, J clin Endocrinol 12: 937. 1952.

64) Purves, H. D., and W. E. Griesbach, Brit J exp Path 27: 170.1946.

65) Goldberg, R.C., and I. L. Chalkofe, Endocrinol 50: 115-123. 1952.
66) Dawson, A.B., Amer J Anat 78: 347-410. 1946.

67) Dawson, A. B., Anat Rec 102: 103-122. 1948.

68) Pearse, A. G. E., J Endocrinol 7: 48-50. 1951.

69) Dawsan, A.B., Anat Rec 120: 810. 1954.

70) Hеaтн, E. H., Amer J Vet Res 26: 368-373. 1967.

71) Racadot, J., Cytologie de l'Adenohypophyse. Ed du C. N. R.S. Paris. 1963.

72) Adamus, C.W.M., and A.G.E. Pearse, J Endocrinol 18: 147-153. 1959.

73) Rennels, E. G., $Z$ Zellforsch 45: 464-471. 1957.

74) Hildebrand, L. E., E. G. Rennels, and J.C. Finerty, Z Zellforsch 46: 400-411. 1957.

75) Hellbaum, A. A., L. G. McArthur, P. J. CAMpbell, and J. C. Finerty, Endocrinol 68: 144-153. 1961.

76) Berrnett, R. J., E. J. Ladman, N. J. MCAllaster, and E. R. Siperstein, Endocrinol 59: 398-418. 1956.

77) Snino, M., J. Fac Agr Miyazaki Univ 9: 53-59. 1963.

78) Ezrin, C., and S. Murray, Cytologie de l'Adenohypophyse. Ed du C. N. R. S. Paris. 1963.

79) Pearse, A.G. E., and S. Van Noodden, Canad Med Ass J 88: 462-471. 1963.

80）見上皆一，岩大墨報 3: 62-68. 1956.

81) Racadot, J., C R Acad Sci (Paris) 257: 19701973. 1963.

82) Conn, A. A., Fed Proc 10: 558-559. 1951.

83) Leznoff, A., J. Fishman, L. Goodfriend, E. McGarry, J. Beck, and B. Rose, Proc Soc $\exp$ Biol Med 104: 232-235. 1960.

84) STOKEs, H., and J.M. BODA, Endocrinol 83: 1362-1366. 1968.

85) Rümke, P., and N. C. J. J. Ladiges, Z Zellforsch 67: 575. 1965.

86) Parker, M.L., L. Jarett, D. S. Schach, and D. M. Kipnis, Endocrinol 76: 928-932. 1965.

87) Emmart, E. W., S. S. SPICER, and R.W. Bates, J Histochem Cytochem 11: 365-373. 1963.

88) Emmart, E. W., R. W. Bates, and W. A. Turner, J Histochem Cytochem 13: 182-190. 1965.

89) Shino, M., and E. G. Rennels, Texas Rep Biol Med 24: 659-673. 1966.

90) Nayak, R., E. E. McGarry, and J.C. Beck, Endocrinol 83: 731-738. 1968.

91) Breustedt, von H-J., Endokrinogie 53: 1-19. 1968.

92) Dubors, M.P., Z Zellforsch 125: 200-209. 1972.

93) McGarry, E. E., L. Ambe, R. Nayak, E. Birch, 
and J.C. BECK, Metabolism 13: 1154. 1964.

94) McGarry, E.E., J.C. Beck, L. Ambe, and R. NAYAK, Rec Progr Horm Res 20: 1. 1964.

95) Brozman, M., Acta. Histochem (Jena) 26: 261-270. 1967.

96) Miogley, A. R. Jr., J Histochem Cytochem 14: 159. 1966.

97) KRACHT, J., U. HaChMEISTER, and H-J. BreUSTEDT, Symp Deut Gesel Endokrinologie, 331335. 1967.

98) Kracht, J., U. Hachmeister, H-J. Breustedt, and Zimmerman, H.-D. Mater Med Nordmark 19: 224-238. 1967.

99) Dubors, M-P., Bull Assoc Anat 54 Congr: 139-146. 1969.

100) Nakane, P.K., and G. B. Pierce, Jr., J Cell Biol 33: 307-318. 1967.

101) Nakane, P.K., J Histochem Cytochen 18: 9-20. 1970.

102) Baker, B. L., A. R. Midgley, B. E. Gersten, and $Y-Y$ Yo, Anat Rec 164: 163-172. 1969.

103) BAKer, B. L., S. PeK, A. R. Midgley Jr., and B. E. Gersten, Anat Rec 166: 557-568. 1970.

104) BAKER, B. L., and $Y-Y$ Yu, Amer $J$ Anat 131: 55-72. 1971.

105) Baker, B. L., J. G. Pierce, and J.S. Cornell, Amer J Anat 135: 251-268. 1972.

106) Tougard, C., B. Kerdelhue, A. Tixier-Vidal, and M. Jutisz, J Cell Biol 58: 503-521. 1973.

107) FerNández-Morán, H., and R. Luft, Acta Endocrinol 2: 199-211. 1949.

108) Rinehart, J. F., and M. G. Farquhar, J Histochem Cytochem 1: 93-113. 1953.

109) Farquhar, M. G., and J. F. Rinehart, Endocrinol 54: 516-541. 1954.

110) Farquhar, M. G., and J.F. Rinehart, Endocrinol 55: 857-876. 1954.

111) Farquhar, M. G., and J.F. Rinehart, Anat Rec 121: 394. 1955.

112) Barnes, B. G., Endocrinol 71: 618-628. 1962.

113) Barnes, B.G., Cytologie de l'Adenohypo. physe, Ed C. N. R. S. Paris. 1963.

114) Kurosumi, K., Arch histol jap 29: 329-362. 1968.

115) Herlant, M., Cytologie de l'Adenohypophyse, Ed C. N. R.S. Paris. 1963.

116) Herlant, M., Int Rev Cytol 17: 299-381. 1964.

117) Smith, R. E., and M.G. Farquhar, J Cell Biol 31: 319-347. 1966.
118) Smith, R.E., and M. G. Farquhar, J Histochem Cytochem 18: 237-250. 1970.

119) Mikami, S., Proc Japan Acad 48: 121-126. 1972.

120) Salazar, H., and R. R. Peterson, Amer J Anat 115: 199-216. 1964.

121) Rennels, E. G., Amer I Anat 114: 71-91. 1964.

122) Potliege, P. R., Anat Rec 160: 595-605. 1968.

123) McShan, W. H., Proc II Int Congr Endocrinol 382-391. 1964.

124) Hymer, W. C., W.H. MCShan, and R. G. Christiansen, Endocrinol 69: 81-90. 1961.

125) Hymer, W.C., and W.H. McShan, J Cell Biol 17: 67-86. 1963.

126) Farquhar, M. G., Anat Rec 127: 291. 1957.

127) KagaYama, M., Endocrinol 77: 1053-1060. 1965.

128) Kurosumi, K., and Y. KobaYashi, Endocrinol 78: 745-758. 1966.

129) Kurosumi, K., and $Y$. Kobayashi, Gunma Symp Endocrinol 6: 213-229. 1269.

130) Rennels, E.G., and M. Shino, Arch d'Anat Hist Embr 51: 575-590. 1968.

131) Stperstein, E. R., and K.J. Mrller, Endocrinol 86: 451-486. 1970.

132) Siperstein, E. R., and V.F. Allison, Endocrinol 76: 70-79. 1965.

133) Herlant, M., and J. Klastersky, C R Ass Anat 118: 720. 1963.

134) YaMADA, K., and K. Yamashita, Z Zellforsch 80: 29-43. 1967.

135) DekKar, A., Anat Rec 158: 351-368. 1967.

136) Dingemans, K. P., J Ultrastr Res 26: 480500. 1969.

137) Yoshimura, F., K. Harumiya, H. Yach, T. Sojr, and T. Yoroyama, Endocrinol japon 20: 181-198. 1973.

138) Harumiya, K., Endocrinol japon 19: 461-475. 1972.

139) Kunosumi, K., and Y. Oотя, Z Zellforsch 85: 34-46. 1968.

140) Girod, C., and P. Dubors, J Ultrastr Res 13 : 212-232, 1965.

141) SAlazAR, H., Anat Rec 147: 469-497. 1963.

142) Rennels, E. G., Cytologie de l'Adenohypophyse, Ed C. N. R.S. Paris. 1963.

143) Shino, M., A. Arimura, A. V. Schally, and E. G. RenNels, Z Zellforsch 128: 152-161. 1972 . 